\title{
Study and Practice of Teaching Reformation of Basic Electricity Market Course
}

\author{
Yajing Gao, Jing Zhu, Fushen Xue, Yongjian Sun, Haifeng Liang \\ School of Electrical and Electronic Engineering \\ North China Electric Power University \\ Baoding, China \\ commoncat@163.com(Y.G.)
}

\begin{abstract}
Basic Electricity Market Course is a significant professional course opened for undergraduates especially students of the Department of Electrical Engineering, which involves Power System, Economic Management, Mathematics and Politics and so on, having plenty of different characteristics from other courses. In North China Electric Power University, this course is available for both the Department of Economic Management and the Department of Electrical Engineering, of which the designs and modes of teaching vary from teaching objects greatly. Furthermore, on the background of Smart grid and the construction of Energy Internet, it is of great significance to carry on the teaching study and reform of this course in order to cultivate electric power talents suits the time. This paper puts out a reformation in teaching content, teaching method, and evaluation mode and so on, with practical reform results to analyze the effects of teaching reformation of this course.
\end{abstract}

Keywords-electricity market; teaching reformation; new electric change plan; energy internet

\section{INTRODUCTION}

Electricity market includes both generalized and narrow sense two kinds of definitions. The generalized definition indicates the sum of the relationship of electricity production, transformation, usage and marketing. While the narrow sense refers to competitive electricity market on which the producer and user of electricity trade on electric energy and its relevant products through negotiation and bidding, fixing price and quantity by market competition[1-2].

"Basic Electricity Market" is a limited optional course for undergraduates of the Department of Electrical Engineering and Agricultural Electrification and Automation of North China Electric Power University, which starts in the first semester of fourth academic year and is available for students majoring in Power System and Automation, Power System Protective Relaying, High Voltage and Insulation Technology, Agricultural Electrification and Automation and so on. Over the years, this course, which contains 24 class hours and 1.5 credits, has been popular among undergraduates and the student number increases gradually, from 48 in year 2013 up to 75 in year 2014 and 86 in 2015 . Year 2013 to 2015 is exactly the time when reformation of industries based upon network that Chinese new government brought out. From the realization of electric change plan in Shenzhen to the procedure of the publish of electric change plan paper No.9, it is thus clear that

This work was supported by the Teaching Reformation Fund Project of North China Electric Power University. the concentration that students put into electricity market and electric power reform elevates gradually to make a acquaintance of the development of electric industry as well as master the reform direction.

Faced with searching for jobs or taking the postgraduate examination, most of the students who attend Basic Electricity Market are at their fourth grade. Hence it is of vital significance for teaching reformation to choose proper teaching content to guarantee the teaching effects, in addition, satisfy the needs of job hunting and postgraduate examination to inspire activity and initiative of students to raise the attendance rate.

Moreover, with the development of Smart grid, Energy Internet and the reformation of Chinese electricity market, the problem of the marketization of electric industry has drawn more and more attention. Why and how to carry out the reformation of electric industry marketization as well as the changes and the challenges for this industry and workers are hotspot issues among research workers and students. Consequently, expanding course contents and bringing these new hot topics into class will do great help in cultivating the activity and initiative of students.

All in all, this paper would discuss the ways and effects of teaching reformation of Basic Electricity Market, from the perspective of course context, teaching methods, evaluation methods, etc, to satisfy the students' needs, inspire students' enthusiasm and improve students' ability of innovation and practicing, which would make teaching keep up with the development pace of the Smart grid, Energy Internet and the process of electric industry reform.

\section{THE CHARACTERISTICS OF BASIC ELECTRICITY MARKET COURSE}

\section{A. Tight Combination of Basic Electricity Market Course and Economics}

The development of electricity market and Economics are closely connected. Firstly, the economic theories in electricity market are emphasized, because Microeconomics is the basis of electricity market while electricity market belongs to oligopoly market in Economics, according to the popular teaching materials of electricity market, including the one written by Professor Du Huaisong in China Agricultural University and the book which Professor Wang Xifan from 
Xi'an Jiaotong University wrote; Secondly, electricity market fits the theory of price equilibrium and the theory of balanced supply and demand; Moreover, being the inelastic necessities, the electric price and consumption of electricity market have relationships that fit the elasticity of price and demand, the production and business models of which belongs to necessities' models. At last, the Game Theory used for oligopoly market is widely applied to the study of bidding, financial transmission right and market power of electricity market [3]. It is visible that solid foundation of Economics is essential for this course. As a result, faced with the students of electricity of few knowledge of Economics, it is worth thinking that how to spread the Microeconomics knowledge to students and guide them to combine Economics and electric industry together.

\section{B. The Influence of Smart Grid and Energy Internet to Basic Electricity Market Course}

With the development of Smart grid, Energy Internet and Smart city, large mounts of distributed generation are connected to the power grid, especially wind power and photovoltaic. Additionally, in user side, single fixed power price are gradually replaced by TOU power price and real-time pricing. As a result, the marketization of electric industry has become the foundation of the existence of intelligent electricity, Energy Internet and Smart city. How and how much the marketization of electric industry will go turn out to be one of the most concerned problems in new circumstance [4-6].

\section{Single Evaluation Mode in Basic Electricity Market Course}

Before the teaching reformation, the evaluation mode of Basic Electricity Market Course is single, either by examination or by writing a paper. If the class ends with a examination, the application of quantities of economic and reform contents is unable to show owing to the limited content; If everyone hands in a paper, considering no concrete judging standard, a big majority of the students will work out reviews without making full use of knowledge learned in the class.

\section{REFORM IDEAS OF BASIC ELECTRICITY MARKET COURSE}

\section{A. Reform of Teaching Content}

With respect to the establishment of teaching content, previous way of taking textbooks materials as main lecture content is changed to some degrees. Based on textbooks, contents regarding Microeconomics are added to enhance knowledge about economic theories in electricity; besides, details of smart grid especially intelligent power utilization are added as supplement, aiming at the combination between electricity market and smart grid in students' perception. Furthermore, Energy Internet is considered in teaching content, with the development orientation of Energy Internet and electricity market's role in it being analyzed; Additionally, smart city is added, and the development of intelligent power utilization in smart city is discussed; Moreover, new progress of electricity market reform especially in China is added, and varies reform situations in different province is shown in class, and thus students are able to do appropriate choices on the basis of different districts.

\section{B. Reform of Teaching Methods}

Oral teaching method is no longer the only mode and method in teaching, and instead, diverse auxiliary teaching means are blended in class.

1) Establishment of Wechat platform: Wechat, the burgeoning communication tool and propaganda tool, can be utilized adequately in teaching progress. Proper utilization of Wechat is beneficial for expanding students' knowledge by not merely self-editing but also forwarding some meaningful contents. What's more, Wechat offers the platform for discussing and advancing one's own viewpoints.

2) Settings of public teaching email boxes: resources shared by teachers and students can be downloaded and learned In this way, the latest bibliography, program and ideas can be co-discussed.

3) Application of questionnaire: considering there is much content in research subject, to acquire ideas of students and their degree of mastering courses, accordingly, questionnaire in each class mainly consisting of choice questions is carried out so that learning contents are consolidated and students' situations are achieved through 5 minutes[7].

\section{Reform of Examination Methods}

Regarding examination methods, diversified examination system is implemented. On basis of students' opinions acquired from questionnaire, they are allowed to choose exam methods, in which session reports, open-book exam and grouped seminar reports are included, and regular grades are reflected through questionnaire and $\log$ in class. As for session reports, set upper limit of the grades 70; As regard to grouped seminar reports, students choosing this project can freely team up with 3 people in each group, firstly a specific forecast case is selected through teachers' interview, then study and analyses of programming are carried out, finally make PowerPoint to demonstrate and answer questions in class during a given time, and corresponding grades are determined by teachers and students. With respect to open-book exam, the examination content stems from teacher's lectures and groups' report. In order to inspect students' ability in problem solving, more opening questions that deserve discussion are brought out in the examination.

\section{RESUlts ANALYSIS OF BASIC ELECTRICITY MARKET COURSE TEACHING REFORMATION}

The 3-year course reformation practice of Basic Electricity Market has made great progress.

\section{A. The Formation of Rich Teaching Content}

A set of new teaching content has been preliminarily formed through the recent 3 -year accumulation. The content of teachers teaching is arranged as follows:

- The analysis of the definition and the basic characteristics of the electricity market.

- Microeconomics in electricity market.

- The development and inspiration of the power industry abroad. 
- The latest trends in the reformation of the power industry in China.

- The smart grid and the smart power.

- The smart city and the Energy Internet.

Generally there are some choices for the students to present:

- The realization of the demand response.

- Electric vehicles and electricity market.

- Environmental issues and electricity market.

- Specific examples of the Energy Internet.

- The new challenges to the traditional problems of the power system in the market environment, etc.

Rich teaching contents, especially the presentation of the students, has improved the students' interests and motivation to learn. After making their own choices on contents related to the Basic Electricity Market course, students either form their own opinions and ideas or put out designed models and solve them out by programming themselves with the discussion with the teacher ahead. On this way, not only can the students' ability of analyzing and solving problems be improved, but also can the shortcomings be made up, which are very difficult for the teacher to focus on among all the numerous details of the electricity market development.

Facts have proved that no fixed teaching content and the way that students make a presentation about the problems is welcomed by most students. It has been shown that the teaching reformation is effective by the increase of course number and the attendance rate and the discussion between teacher and students after class.

\section{B. The Formation of Abundant Examination Form}

Abundant optional examinations allow students to have the right to choose. They can choose the examination form according to their own needs and time. It avoids the situation in which the senior students can't attend the class and examination because they have to prepare for the exams for postgraduate schools or look for jobs. Students can choose to write an essay as the class-ending mode if necessary. Although they may not get a high score, but they can continue to learn after class and get the credit. The form of group-presentation, which takes more time, is suitable for the students who has been recommended for admission to be a postgraduate or has found a job. They can spend more time on it to refine their research directions in the future, or practice their ability of solving problems, preparing for their jobs. The traditional exam is a good choice for the students who want a high score. They learn knowledge in the class and think deeply about the issues, which is helpful for them to learn more and get a satisfactory score in the same time.

In the 3-year practice, about half of the students chose exam as class-ending mode, and 30 percentage of the students chose grouped seminar report, while only 20 percentage chose class-ending paper, illustrating that only a small part of students requested fewer conditions for grades, while a larger proportion of students dared to try reformation, hoping to improve both good grades and practical programming and lecture abilities through practical operation. Fig. 1 shows the final analysis of grades satisfaction degree, in which most of the students are satisfied with final grades and only rare students feel rather ordinary, indicating students' recognition for teaching and reformation.

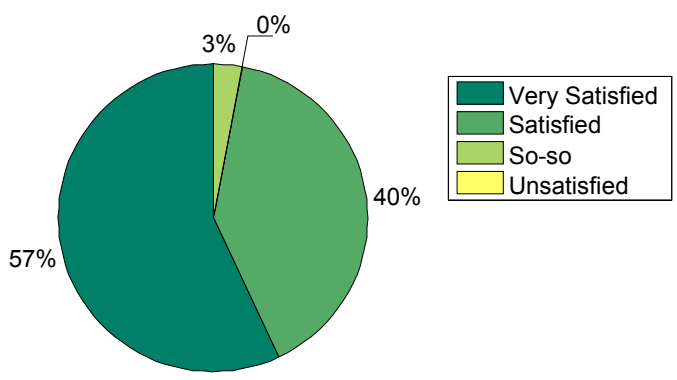

Fig. 1. The analysis and investigation of the final scores satisfaction degree

\section{Popular Wechat Public Platform and Wechat Group}

The establishment of Wechat public platform and Wechat group brings a new type of communication space for teachers and students. Paying attention to new trends in electric industry, lots of students love to share and have discussion about them by this new social way in their spare time, which benefits both teacher and students.

\section{CONCLUSION}

This paper has proposed a new design thought of course reformation of Basic Electricity Market Course, based on the analysis of this course's characteristics and the new requirement under the background of smart grid and Energy Internet:

1) Enrich course content by introducing topics of smart grid, Energy Internet, smart city, etc;

2) Employ Wechat group and platform, provide public email and adopt questionnaire to ensure interactive communication;

3) Reform examination ways and students could choose one or more from ways provided.

It is proved that the reformation has made great progress and provided new thoughts for other course reformations of Electrical Engineering.

\section{REFERENCES}

[1] Huaisong Du, "Electricity market," Beijing: China Electric Power Press, 2004.

[2] Xifan Wang, "Basic electricity market," Xi'an: Xi'an Jiaotong University Press, 2003.

[3] Paul A. Samuelson, William D. Nordhaus, "Microeconomics," Beijing: Posts \&Telecom Press, 2010.

[4] Zhenya Liu, "Global Energy Internet," Beijing: China Electric Power Press, 2015. 
[5] Shiming Tian, "Technology for smart grid," Beijing: China Electric Power Press, 2014.

[6] Hui Wang, Yue Wu, Jianqiang Zhang, Jalin Qiu and Wen Xiaoyue, "Smart city," Beijing: Tsinghua University Press, 2012.
[7] Lihui Liu, "Questionaire analysis of college English teaching reformation," Jian Nan Wenxue, 2011, 10: 93-94. 